\title{
FORMULASI DAN UJI AKTIVITAS ANTIOKSIDAN KRIM EKSTRAK ETANOL DAUN MURBEI (Morus alba L.) MENGGUNAKAN METODE DPPH (1,1-Diphenyl-2-Picrylhydrazyl)
}

\section{FORMULATION AND ANTIOXIDANT ACTIVITY TEST OF MULBERRY LEAF (Morus alba L.) ETHANOL EXTRACT CREAM USING DPPH (1,1-Diphenyl-2-Picrylhydrazyl) METHOD}

\author{
Eklesia Pogaga ${ }^{1)}$, Paulina V.Y Yamlean ${ }^{1)}$, Julianri Sari Lebang ${ }^{1)}$ \\ 1) Program Studi Farmasi FMIPA UNSRAT Manado, 95115 \\ *eklesiapgaga@gmail.com
}

\begin{abstract}
Mulberry is one of the plants growing in Indonesian and widely used as traditional medicine. The active compounds found in Mulberry leaves are known have an antioxidant activity. The aim of this study is to formulate cream preparations from ethanol extracts of Mulberry leaves and to determine its antioxidant activities. Mulberry leaves was macerated using ethanol 96\%. Antioxidant activity of mulberry leaves cream then evaluated against DPPH as free radical and measured at $517 \mathrm{~nm}$ wavelength using a UV-Vis spectrophotometer. The results showed that the cream of ethanol extract from Mulberry leaves had a very strong antioxidant activity with $I_{50}$ values in a row that is $1.7831 \mathrm{ppm}, 0.8215 \mathrm{ppm}$ and $0.7668 \mathrm{ppm}$. This can be compared with a Vitamin $C$ solution, which has a very strong antioxidant activity with $I_{50}$ value was 1.1113 ppm. This study concludes that the cream from Mulberry leaves ethanol extract has a very strong antioxidant activity.
\end{abstract}

Keywords: Mulberry leaves, Cream, Antioxidant, DPPH

\begin{abstract}
ABSTRAK
Murbei merupakan salah satu tanaman yang tumbuh di Indonesia dan banyak digunakan dalam pengobatan secara tradisional. Kandungan senyawa aktif yang terdapat pada daun Murbei dikenal mempunyai peranan sebagai antioksidan. Tujuan dari penelitian ini ialah untuk membuat sediaan krim dari ekstrak etanol daun Murbei dan untuk menguji apakah adanya aktivitas antioksidan. Daun murbei diekstraksi dengan metode maserasi menggunakan pelarut etanol 96\%. Sediaan krim diuji terhadap DPPH sebagai radikal bebas dan diukur pada panjang gelombang $517 \mathrm{~nm}$ dengan menggunakan spektrofotometer UV-Vis. Hasil penelitian menunjukkan bahwa krim ekstrak etanol daun Murbei memiliki aktivitas antioksidan yang sangat kuat dengan nilai $\mathrm{IC}_{50}$ berturut-turut yaitu $1,7831 \mathrm{ppm}, 0,8215 \mathrm{ppm}$ dan $0,7668 \mathrm{ppm}$. Hal ini dapat dibandingkan dengan larutan Vitamin $\mathrm{C}$ yang mempunyai aktivitas antioksidan yang sangat kuat, yaitu $1.1113 \mathrm{ppm}$. Berdasarkan hasil penelitian dapat disimpulkan bahwa krim dari ekstrak etanol daun Murbei memiliki aktivitas antioksidan yang sangat kuat.
\end{abstract}

Kata Kunci: Daun Murbei, Krim, Antioksidan, DPPH 


\section{PENDAHULUAN}

Radikal bebas sering kita jumpai, baik di luar tubuh maupun di dalam tubuh. Sumber radikal bebas endogen (dari dalam tubuh) yaitu autoksidasi, oksidasi enzimatik dan respyratori burst. Sedangkan sumber radikal bebas eksogen (dari luar tubuh) seperti polusi udara, radiasi UV, sinar-X, asap rokok dan makanan yang mengandung pestisida.

Radikal bebas dibutuhkan tubuh dalam jumlah normal untuk kesehatan, sementara dalam jumlah berlebih akan menyebabkan stress oksidatif. Keadaan tersebut dapat menyebabkan kerusakan oksidatif mulai dari sel, jaringan, hingga ke organ tubuh yang mempercepat terjadinya proses penuaan dan munculnya berbagai penyakit. Oleh sebab itu, antioksidan dibutuhkan untuk dapat menunda atau menghambat reaksi oksidasi oleh radikal bebas (Widiastuti, 2010).

Salah satu tanaman yang memiliki aktivitas antioksidan ialah tanaman Murbei (Morus alba L). Secara empiris, masyarakat telah memanfaatkan tanaman Murbei sebagai obat tradisional untuk masalah kesehatan seperti flu, malaria, hipertensi, asma, diabetes, insomnia, vertigo dan anemia. Kandungan senyawa aktif yang terdapat pada daun Murbei yaitu alkaloid, flavonoid, polifenol dan terpenoid yang mempunyai peranan sebagai antioksidan (Jurian, 2016). Daun Murbei juga memiliki kandungan kimia yang tinggi akan antosianin, fenolik dan komponen asam lemak. Pada penelitian sebelumnya juga menunjukkan bahwa daun Murbei memiliki efek sebagai antioksidan, antibakteri, antivirus, anti inflamasi dan antimikroba (Salem, 2013).

Berdasarkan hasil penelitian yang telah dilakukan oleh Megawati, et al. (2019) menunjukkan bahwa ekstrak etanol daun Murbei yang diuji aktivitas antioksidannya menggunakan metode DPPH memiliki aktivitas antioksidan yang sangat kuat dengan nilai $\mathrm{IC}_{50} 8,35 \mathrm{ppm}$.

Manfaat dari daun Murbei sebagai antioksidan perlu dikembangkan dalam bentuk sediaan yang cocok. Sediaan krim dipilih karena menurut Sharon, et al., (2013), krim memiliki beberapa keuntungan diantaranya lebih mudah diaplikasikan, lebih nyaman digunakan, tidak lengket, dan mudah dicuci dengan air dibandingkan dengan sediaan salep atau pasta.

Berdasarkan uraian di atas, maka peneliti tertarik untuk membuat formulasi dan uji aktivitas antioksidan krim tipe M/A dari ekstrak etanol daun Murbei dengan diambilnya konsentrasi awal sebagai acuan, yaitu sebesar $0,75 \%$. Hal ini didasarkan melalui penelitian yang dilakukan oleh Radhia, et. al. (2017), yang menyatakan bahwa formula krim pemutih ekstrak daun Murbei dengan konsentrasi $0,75 \%$ dapat diformulasikan sebagai sediaan krim.

\section{METODOLOGI PENELITIAN}

\section{Waktu dan Tempat Penelitian}

Penelitian ini dilaksanakan pada bulan Januari 2019 - April 2020. Tempat penelitian dilakukan di Laboratorium Farmasi Lanjut Fakultas Matematika dan Ilmu Pengetahuan Alam, Universitas Sam Ratulangi.

\section{Bentuk Penelitian}

Jenis penelitian ini ialah Deskriptif Analitik dengan menggunakan perlakuan tiga variasi konsentrasi, evaluasi sediaan dan uji aktivitas antioksidan krim terhadap DPPH (1,1-diphenyl-2picrylhidrazyl).

\section{Alat dan Bahan}

Alat

Alat-alat yang digunakan ialah alat-alat gelas (Iwaki ST Pyrex ${ }^{\circledR}$ ), timbangan analitik (AE Adam ${ }^{\circledR}$ ), lumpang dan alu, spektrofotometer UV-Vis, kertas saring, pipet tetes, pipet mikro, beban pemberat, lemari pendingin, oven (Ecocell MMM Group), blender (Miyako ${ }^{\circledR}$ ), hot plate (Nesco ${ }^{\circledR} \mathrm{Lab}$ ), pH meter (Elmeiron), sudip, cawan petri, batang pengaduk, vortex (Mixer Hwashin), ayakan 100 mesh, wadah tempat krim, penggaris, stopwatch dan alluminium foil.

\section{Bahan}

Bahan-bahan yang digunakan, yaitu daun Murbei, DPPH (1,1-diphenyl-2-picrylhidrazyl), Vitamin C, etanol $96 \%$, asam stearat, TEA, adeps lanae, paraffin cair, nipagin, nipasol dan aquades.

\section{Bentuk Penelitian}

Jenis penelitian ini ialah Deskriptif Analitik dengan menggunakan perlakuan tiga variasi konsentrasi, evaluasi sediaan dan uji aktivitas antioksidan krim terhadap DPPH (1,1-diphenyl-2picrylhidrazyl).

\section{Prosedur Penelitian}

\section{Penyiapan dan Pengambilan Sampel}

Sampel yang digunakan pada penelitian ini ialah daun Murbei yang diambil di sekitaran Desa Poniki, Kecamatan Pasan, Kabupaten Minahasa Tenggara, Provinsi Sulawesi Utara. Sampel dikumpulkan sebanyak $3 \mathrm{~kg}$, kemudian dicuci dengan air mengalir agar sampel terbebas dari sisa kotoran. Setelah bersih, daun ditiriskan dan 
diangin-anginkan dalam suhu ruangan selama 5 hari. Selanjutnya, sampel yang telah kering dihaluskan menggunakan blender hingga menjadi serbuk simplisia.

\section{Ekstrasi Sampel}

Metode yang digunakan dalam proses ekstraksi, yaitu metode maserasi dengan menggunakan etanol 96\%. Sebanyak $500 \mathrm{~g}$ serbuk simplisia dimasukkan ke dalam etanol 96\% sebanyak $2500 \mathrm{ml}$ hingga terendam

\section{Formulasi Sediaan Krim Ekstrak Etanol Daun Murbei}

Tabel 1. Formula krim ekstrak daun Murbei semua sambil diaduk-aduk, kemudian disimpan atau didiamkan selama 5 x 24 jam di tempat yang sejuk tanpa adanya paparan sinar matahari sambil sesekali dilakukan pengadukan. Selanjutnya, simplisia yang telah terendam disaring dan dipisahkan (antara residu dan filtrat). Setelah itu, filtrat diuapkan menggunakan oven pada suhu $40^{\circ} \mathrm{C}$ hingga diperoleh ekstrak kental.

\begin{tabular}{lllcc}
\hline \multirow{2}{*}{ Bahan } & Kegunaan & \multicolumn{3}{c}{ Konsentrasi } \\
& & FI & FII & FIII \\
\cline { 3 - 5 } Ekstrak daun Murbei & Zat aktif & $\mathbf{0 , 7 5 \%}$ & $\mathbf{3 , 7 5 \%}$ & $\mathbf{6 , 7 5 \%}$ \\
Asam stearate & Penstabil & 16,75 & 3,75 & 6,75 \\
TEA & Emulgator & 2,5 & 16,5 & 16,5 \\
Adeps lanae & Basis & 3 & 2,5 & 2,5 \\
Paraffin cair & Pembentuk massa & 25 & 3 & 3 \\
Nipagin & Pengawet & 0,1 & 25 & 25 \\
Nipasol & Pengawet & 0,05 & 0,1 & 0,1 \\
Aquades & Pelarut & 52,1 & 49,1 & 0,05 \\
\hline & & & & \\
\hline
\end{tabular}

\section{Pembuatan Krim Ekstrak Etanol Daun Murbei}

Sediaan krim dibuat dalam 3 formulasi ekstrak daun Murbei dengan masing-masing konsentrasi, yaitu FI $0,75 \%$, FII $3,75 \%$ dan FIII $6,75 \%$. Masing-masing bahan ditimbang dan dipisahkan. Pembuatan krim diawali dengan pemisahan fase, yaitu fase minyak (asam stearat, paraffin cair, adeps lanae dan nipasol) dimasukkan ke dalam beaker glass sambil dipanaskan pada suhu dipertahankan $70^{\circ} \mathrm{C}$ dengan menggunakan hot plate. Hal yang sama dilakukan untuk fase air (aquades, nipagin dan TEA). Fase minyak yang telah melebur dituang ke dalam lumpang yang telah dipanaskan, sambil diaduk hingga homogen. Kemudian, ditambahkan fase air sedikit demi sedikit sambil diaduk perlahan-lahan hingga terbentuk massa krim, lalu dimasukkan ekstrak kental daun Murbei ke dalam massa krim sedikit demi sedikit dan diaduk sampai homogen.

\section{Evaluasi Fisik Sediaan Krim}

\section{Uji Organoleptik}

Uji organoleptik sediaan krim dilakukan dengan mengamati warna, bau, dan bentuk krim (Sharon, et al., 2013). Sediaan krim yang dihasilkan sebaiknya memiliki tekstur atau bentuk yang lunak, bau yang menyenangkan dan warna yang menarik.

\section{Uji Homogenitas}

Pengujian homogenitas dilakukan dengan cara, yaitu mengoleskan sediaan pada sekeping kaca atau bahan transparan lain dan diratakan, sediaan krim yang baik harus menunjukkan susunan yang homogen dan tidak terlihat adanya butiran kasar (Depkes RI, 1979).

\section{Uji pH}

Pengukuran $\mathrm{pH}$ dilakukan dengan menggunakan $\mathrm{pH}$ meter. Caranya yaitu dengan menimbang 1 gram krim dan dilarutkan dengan 10 $\mathrm{ml}$ aquades. Kemudian, gunakan $\mathrm{pH}-$ meter yang bagian sensornya dan dibaca $\mathrm{pH}$ pada bagian monitor. $\mathrm{pH}$ sediaan yang memenuhi kriteria $\mathrm{pH}$ kulit yaitu sekitar 4,5 - 6,5 (Tranggono dan Latifa, 2007).

\section{Uji Daya Sebar}

Masing-masing krim ditimbang sebanyak $1 \mathrm{~g}$, lalu diletakan di atas sepasang cawan petri dan dibiarkan selama 1 menit, kemudian diletakan beban sebesar $50 \mathrm{~g}$, beban didiamkan selama 1 menit lalu diukur diameter sebarnya (Rahmawati, et al., 2010).

\section{Uji Daya Lekat}

Ditimbang 0,5 gram krim dan dioleskan pada plat kaca. Kedua plat kaca ditempelkan hingga plat menyatu, diberikan beban seberat 250 gram selama 5 menit setelah itu dilepaskan, lalu diberi beban 
pelepasan. Waktu dicatat sampai kedua plat saling lepas. Berdasarkan persyaratan daya lekat krim yang baik yaitu lebih dari 4 detik (Wasiaatmadja, 1997).

\section{Uji Cycling}

Sediaan disimpan pada suhu $4^{\circ} \mathrm{C}$ selama 24 jam dan dilanjutkan dengan menyimpan sediaan pada suhu $40^{\circ} \mathrm{C}$ selama 24 jam. Kedua perlakuan tersebut merupakan sikus pertama. Pengujian dilakukan sebanyak 6 siklus dan diamati terjadinya perubahan fisik dari sediaan krim pada awal dan akhir pengujian yang meliputi organoleptik, homogenitas, $\mathrm{pH}$, daya sebar dan daya lekat.

\section{Uji Aktivitas Antioksidan Sediaan Krim Pembuatan Larutan Induk DPPH}

Ditimbang DPPH (1,1-difenil-2-picrylhidrazil) sebanyak $10 \mathrm{mg}$, kemudian dilarutkan dalam etanol 96\% hingga tanda batas dengan menggunakan labu ukur $100 \mathrm{ml}$, lalu tempatkan dalam botol kaca berwarna gelap.

\section{Pembuatan Larutan Blanko DPPH}

Larutan Induk DPPH sebanyak $50 \mathrm{ml}$ dimasukkan ke dalam labu ukur 100 ml, kemudian dilarutkan dengan etanol 96\% hingga tanda batas dan dihomogenkan. Didiamkan selama 30 menit dan diukur absorbansinya pada panjang gelombang $517 \mathrm{~nm}$.

\section{Uji Aktivitas Antioksidan Larutan Uji}

Sampel krim sebanyak $10 \mathrm{mg}$ dilarutkan ke dalam etanol 96\% $10 \mathrm{ml}$ dan dicukupkan hingga tanda batas. Larutan sampel krim dibuat dengan masing-masing konsentrasi 50 ppm, 100 ppm, 150 ppm, $200 \mathrm{ppm}$ dan $250 \mathrm{ppm}$. Masing-masing dipipet dan ditambahkan etanol $96 \%$ ke dalam labu ukur $10 \mathrm{ml}$ hingga tanda batas. Dipipet larutan sampel krim sebanyak $2 \mathrm{ml}$ dan ditambahkan ke dalam tabung reaksi yang berisi larutan DPPH sebanyak $2 \mathrm{ml}$, kemudian ditutup menggunakan aluminium foil. Selanjutnya divortex dan didiamkan selama 30 menit, kemudian diukur serapannya menggunakan spektrofotometer UVVis dengan panjang gelombang $517 \mathrm{~nm}$ dan dihitung presentase inhibisinya.

\section{Pembuatan Larutan Pembanding}

Sebanyak $10 \mathrm{mg}$ vitamin C dilarutkan ke dalam etanol $96 \% 10 \mathrm{ml}$ dan dicukupkan hingga tanda batas. Larutan vitamin $\mathrm{C}$ dibuat dengan masing-masing konsentrasi $5 \mathrm{ppm}, 10 \mathrm{ppm}, 15$ ppm, $20 \mathrm{ppm}$ dan $25 \mathrm{ppm}$. Masing-masing dipipet dan ditambahkan etanol $96 \%$ ke dalam labu ukur 5 $\mathrm{ml}$ hingga tanda batas. Dipipet larutan vitamin $\mathrm{C}$ sebanyak $1 \mathrm{ml}$ dan ditambahkan ke dalam tabung reaksi yang berisi larutan DPPH sebanyak $2 \mathrm{ml}$, kemudian ditutup menggunakan aluminium foil. Selanjutnya divortex dan didiamkan selama 30 menit, kemudian diukur absorbansinya dengan menggunakan spektrofotometer UV-Vis pada panjang gelombang $517 \mathrm{~nm}$ dan dihitung presentase inhibisinya.

$\%$ Inhibisi $=\frac{\text { Absorbans Blanko }- \text { Absorbans Uji }}{\text { Absorbans Blanko }} \times 100 \%$

\section{HASIL DAN PEMBAHASAN}

Serbuk simplisia diekstraksi dengan metode maserasi menggunakan pelarut etanol $96 \%$ sebanyak $2500 \mathrm{~mL}$ selama $5 \times 24$ jam yang menghasilkan ekstrak kental daun Murbei seberat 31,77 g. Berdasarkan perhitungan dengan rumus, diperoleh nilai rendemen sebesar 6,35\%.

Evaluasi Fisik Sediaan Krim Uji Organoleptik

Tabel 2. Hasil uji organoleptik (siklus 0-6)

\begin{tabular}{|c|c|c|}
\hline \multirow{2}{*}{ Sediaan } & \multicolumn{2}{|r|}{ Pengamatan } \\
\hline & Bentuk & Warna \\
\hline FI $(0,75 \%)$ & Semi solid & Khas adeps lanae \\
\hline FII $(3,75 \%)$ & Semi solid & Khas adeps lanae \\
\hline FIII $(6,75 \%)$ & Semi solid & Khas adeps lanae \\
\hline $\begin{array}{l}\text { Sifat-sifat fisik se } \\
\text { bau dan warna a } \\
\text { penerimaan dan kenya } \\
\text { sediaan krim yang dih } \\
\text { tekstur yang lunak, ba } \\
\text { warna yang mena }\end{array}$ & $\begin{array}{l}\text { im seperti bentuk, } \\
\text { hubungan dengan } \\
\text { pengguna, di mana } \\
\text { sebaiknya memiliki } \\
\text { menyenangkan dan } \\
\text { lasil pengamatan }\end{array}$ & $\begin{array}{l}\text { organoleptis krim Formula I, Formula II dan } \\
\text { Formula III dari siklus ke-0 hingga siklus ke-6, } \\
\text { menunjukkan bahwa krim memiliki warna yang } \\
\text { berbeda-beda dari tiap konsentrasi. Dengan adanya } \\
\text { perubahan warna dari tiap konsentrasi, } \\
\text { menunjukkan bahwa penambahan ekstrak daun } \\
\text { Murbei dalam basis krim mempengaruhi warna }\end{array}$ \\
\hline
\end{tabular}


dari sediaan krim, yaitu semakin besar konsentrasi ekstrak yang terkandung di dalam krim, maka semakin pekat pula warna yang dihasilkan oleh krim.

Stabilitas krim dapat dilihat melalui perlakuan dari siklus ke-0 hingga siklus ke-6. Ketiga formula krim tidak mengalami perubahan baik dari segi

Tabel 3. Hasil uji homogenitas warna, bentuk, maupun bau setelah dilakukan penyimpanan selama 12 hari. Hal tersebut dapat dikatakan bahwa ketiga formula krim dengan berbagai konsentrasi tetap stabil selama proses penyimpanan.

\begin{tabular}{cccc}
\hline Siklus & & Pengamatan & \\
\cline { 2 - 4 } Konsentrasi 0,75\% & Konsentrasi 3,75\% & Konsentrasi 6,75\% \\
\hline 0 & Homogen, tidak menggumpal & Homogen,tidak menggumpal & Homogen, tidak menggumpal \\
1 & Homogen, tidak menggumpal & Homogen, tidak menggumpal & Homogen, tidak menggumpal \\
2 & Homogen, tidak menggumpal & Homogen, tidak menggumpal & Homogen, tidak menggumpal \\
3 & Homogen, tidak menggumpal & Homogen, tidak menggumpal & Homogen, tidak menggumpal \\
4 & Homogen, tidak menggumpal & Homogen, tidak menggumpal & Homogen, tidak menggumpal \\
5 & Homogen, tidak menggumpal & Homogen, tidak menggumpal & Homogen, tidak menggumpal \\
6 & Homogen, tidak menggumpal & Homogen, tidak menggumpal & Homogen, tidak menggumpal
\end{tabular}

Pengujian homogenitas sediaan krim ekstrak etanol daun Murbei dari siklus ke-0 hingga siklus ke-6, menunjukkan bahwa ketiga konsentrasi sediaan krim memiliki sifat fisik yang homogen dan tidak terdapat gumpalan atau butiran-butiran kasar. Hal ini menunjukkan bahwa semua bahan krim telah tercampur dengan baik. Pernyataan tersebut sesuai dengan syarat uji homogenitas sediaan krim, bahwa krim harus menunjukkan susunan yang homogen dan tidak terlihat adanya butiran-butiran kasar (Depkes, 1979). Sifat tersebut akan memungkinkan krim mudah digunakan dan terdistribusi merata pada permukaan kulit.

Berdasarkan hasil pengamatan dari siklus ke- 0 hingga siklus ke-6, ketiga formula krim tidak mengalami perubahan fisik selama penyimpanan (12 hari) pada suhu $4{ }^{\circ} \mathrm{C}$ maupun pada suhu $40^{\circ} \mathrm{C}$. Dengan demikian, krim yang dihasilkan dapat dinyatakan memiliki stabilitas yang baik.

Tabel 4. Hasil uji pH

\begin{tabular}{cccc}
\hline \multirow{2}{*}{ Siklus } & \multicolumn{3}{c}{ Nilai rata-rata pH } \\
\cline { 2 - 4 } & Konsentrasi 0,75\% & Konsentrasi 3,75\% & Konsentrasi 6,75\% \\
\hline 0 & 5,90 & 5,25 & 5,16 \\
1 & 5,56 & 5,30 & 5,95 \\
2 & 5,39 & 5,00 & 5,76 \\
3 & 5,30 & 5,07 & 5,12 \\
4 & 5,88 & 5,90 & 5,72 \\
5 & 6,00 & 5,71 & 5,95 \\
6 & 5,97 & 5,91 & 5,86 \\
\hline
\end{tabular}

Pengujian $\mathrm{pH}$ sediaan krim harus sesuai dengan $\mathrm{pH}$ kulit supaya tidak terjadi iritasi atau reaksi lainnya pada kulit. Menurut Tranggono dan Latifah, (2007) kriteria $\mathrm{pH}$ kulit yang baik yaitu berada dalam interval 4,5-6,5. Hasil dari ketiga sediaan krim dengan konsentrasi yang berbeda pada siklus ke-0 hingga siklus ke-6 memiliki $\mathrm{pH}$ interval yang tidak kurang ataupun tidak lebih dari kriteria $\mathrm{pH}$ kulit pada umumnya. Sehingga dapat dikatakan formula krim dari konsentrasi $0,75 \%$; $3,75 \% ; 6,75 \%$ memiliki $\mathrm{pH}$ yang sesuai dengan $\mathrm{pH}$ kulit atau dapat dikatakan aman apabila diaplikasikan pada kulit.

Kestabilan $\mathrm{pH}$ dalam suatu sediaan juga perlu perhatikan apabila terjadinya perubahan $\mathrm{pH}$ yang tidak signifikan. Dengan ini, maka dilakukan pengujian statistika menggunakan Independent $T$ test untuk mengetahui apakah adanya 
perbandingan bermakna suatu $\mathrm{pH}$ krim dari siklus ke-0 hingga siklus ke-6. Hasil data statistika dari sediaan krim dengan konsentrasi $0,75 \%$, diperoleh nilai signifikansi sebesar 0,716 (sig $>0,05)$. Pada sediaan krim dengan konsentrasi $3,75 \%$, memiliki nilai signifikansi sebesar 0,109 (sig >0,05). Hal yang sama juga terdapat pada sediaan krim dengan konsentrasi $6,75 \%$ dengan perolehan nilai signifikan sebesar 0,159 ( $\operatorname{sig}>0,05 \%$ ), artinya tidak ada perbedaan nilai $\mathrm{pH}$ yang bermakna pada ketiga krim dari siklus ke-0 hingga siklus ke-6. Hal ini menunjukkan bahwa nilai $\mathrm{pH}$ sediaan krim ekstrak etanol daun Murbei memiliki pH yang stabil selama proses penyimpanan pada suhu tertentu.

Tabel 5. Hasil uji daya sebar

\begin{tabular}{cccc}
\hline \multirow{2}{*}{ Siklus } & \multicolumn{3}{c}{ Nilai rata-rata daya sebar $(\mathbf{c m})$} \\
\cline { 2 - 4 } & Konsentrasi $\mathbf{0 , 7 5 \%}$ & Konsentrasi 3,75\% & Konsentrasi 6,75\% \\
\hline 0 & 5 & 6,1 & 6,37 \\
1 & 5,07 & 5,73 & 5,90 \\
2 & 5,13 & 5,47 & 6,03 \\
3 & 5,03 & 5,6 & 6,37 \\
4 & 5,20 & 5,77 & 6,20 \\
5 & 5,13 & 5,87 & 5,67 \\
6 & 5,07 & 5,57 & 5,97 \\
\hline
\end{tabular}

Pengujian daya sebar pada ketiga sediaan krim ekstrak etanol daun Murbei dari siklus ke-0 hingga siklus ke-6, memiliki nilai rerata yang berbedabeda. Adanya perubahan diameter daya sebar pada sediaan krim dengan berbagai konsentrasi menunjukkan bahwa penambahan variasi konsentrasi ekstrak, berpengaruh terhadap luas penyebaran sediaan krim. Sediaan krim dengan diameter daya sebar yang besar akan memudahkan krim menyebar pada permukaan kulit, sehingga absorbsi senyawa antioksidan yang terkandung dalam krim akan semakin meningkat.

Tabel 6. Hasil uji daya lekat
Berdasarkan hasil data statistika uji daya sebar dari sediaan krim dengan konsentrasi 0,75\%, diperoleh nilai signifikansi sebesar 0,374 (sig $>0,05$ ). Pada sediaan krim dengan konsentrasi $3,75 \%$, memiliki nilai signifikansi sebesar 0,011 (sig >0,05). Hal yang sama juga terdapat pada sediaan krim dengan konsentrasi $6,75 \%$ dengan perolehan nilai signifikan sebesar 0,033 (sig $>0,05 \%$ ), artinya tidak ada perbedaan luas daya sebar yang bermakna pada ketiga krim dari siklus ke-0 hingga siklus ke-6. Hal ini menunjukkan bahwa luas daya sebar sediaan krim ekstrak etanol daun Murbei memiliki nilai yang cukup stabil selama proses cycling test.

\begin{tabular}{cccc}
\hline Siklus & \multicolumn{3}{c}{ Nilai rata-rata daya lekat (menit) } \\
\cline { 2 - 4 } & Konsentrasi $\mathbf{0 , 7 5 \%}$ & Konsentrasi 3,75\% & Konsentrasi 6,75\% \\
\hline 0 & 0.98 & 1.26 & 1.16 \\
1 & 1.54 & 0.80 & 1.30 \\
2 & 0.94 & 0.62 & 0.86 \\
3 & 1.06 & 0.62 & 0.90 \\
4 & 1.23 & 1.06 & 0.46 \\
5 & 0.98 & 0.93 & 0.64 \\
6 & 1.29 & 0.83 & 0.79
\end{tabular}

Kemampuan sediaan krim untuk melekat pada tempat aplikasi sangat penting. Daya lekat merupakan salah satu karakteristik yang bertanggung jawab terhadap keefektifan sediaan dalam memberikan efek farmakologis. Semakin lama daya lekat suatu sediaan pada tempat aplikasi, maka efek farmakologis yang dihasilkan akan semakin besar. Pada saat pemberian beban pelepasan, terjadi pelepasan antara kedua plat, maka waktu tersebut merupakan lama waktu kontak krim dengan kulit hingga efek terapi yang diinginkan dapat tercapai. 
Berdasarkan hasil pengujian daya lekat sediaan krim dengan berbagai konsentrasi dari siklus ke- 0 hingga siklus ke-6 terdapat nilai yang tidak konsisten, meski telah dilakukan tiga kali pengulangan. Pengulangan uji daya lekat bertujuan untuk mendapatkan nilai yang lebih akurat. Hal ini diasumsikan karena alat pengujian yang digunakan masih dilakukan secara manual, sehingga hasil yang diperoleh masih kurang akurat.

Selain itu, pengujian daya lekat juga dilakukan pengujian statistika, yaitu mengunakan Independent T-test untuk mengetahui apakah adanya perbedaan bermakna daya lekat krim dari siklus ke-0 hingga siklus ke-6 dari berbagai konsentrasi. Sediaan krim dengan konsentrasi $0,75 \%$, diperoleh nilai signifikansi sebesar 0,305 (sig >0,05). Pada sediaan krim dengan konsentrasi $3,75 \%$, memiliki nilai signifikansi sebesar 0,158 (sig >0,05). Hal yang sama juga terdapat pada sediaan krim dengan konsentrasi $6,75 \%$ dengan perolehan nilai signifikan sebesar 0,313 (sig $>0,05 \%$ ), artinya tidak ada perbedaan daya lekat yang bermakna pada ketiga krim dari siklus ke-0 hingga siklus ke-6, sehingga dapat dikatakan krim memiliki daya lekat yang stabil.

Tabel 7. Hasil uji aktivitas antioksidan

\begin{tabular}{ccc}
\hline Sediaan & \multicolumn{1}{c}{ Persamaan regresi } & IC $_{\mathbf{5 0}}(\mathrm{ppm})$ \\
\hline FI $(0,75 \%)$ & $\mathrm{y}=4.689 \mathrm{x}+41.639 ; \mathrm{R}^{2}=0.9794$ & 1,7831 \\
FII $(3,75 \%)$ & $\mathrm{y}=3.195 \mathrm{x}+47.375 ; \mathrm{R}^{2}=0.9532$ & 0,8215 \\
FIII $(6,75 \%)$ & $\mathrm{y}=3.903 \mathrm{x}+47.007 ; \mathrm{R}^{2}=0.973$ & 0,7668 \\
Vitamin C & $\mathrm{y}=8.297 \mathrm{x}+40.779 ; \mathrm{R}^{2}=0.8936$ & 1,1113 \\
\hline
\end{tabular}

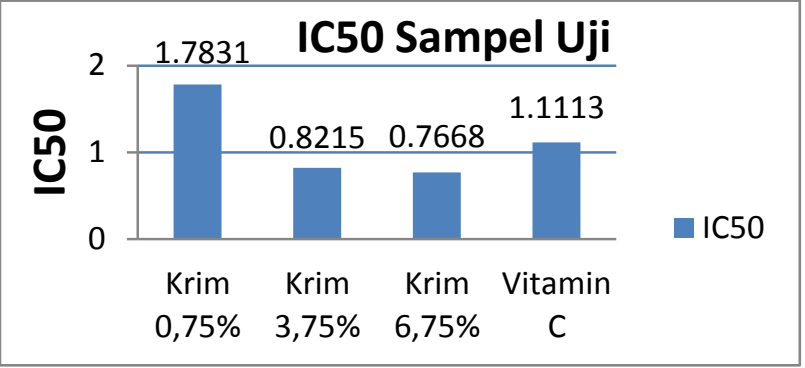

Gambar 1. Grafik uji aktivitas antioksidan

Pengujian aktivitas antioksidan dilakukan dengan menggunakan metode DPPH (1,1diphenyl-2-picrylhidrazyl). Metode ini dipilih karena hanya memerlukan sedikit sampel, lebih peka, sederhana, mudah dan cepat (Hanani, et al., 2005). Panjang gelombang maksimum DPPH yang didapat untuk pengukuran aktivitas antioksidan ekstrak etanol daun murbei adalah $517 \mathrm{~nm}$, dengan menggunakan spektrofotometer UV-Vis. Parameter yang digunakan untuk menunjukan aktivitas antioksidan adalah Inhibition concentration $\left(\mathrm{IC}_{50}\right)$. Nilai $\mathrm{IC}_{50}$ merupakan nilai yang menunjukan konsentrasi antioksidan yang mampu menghambat 50\% aktivitas radikal bebas (Haeria dan Andi, 2016).

Secara kimia senyawa antioksidan adalah senyawa pemberi elektron (donor elektron). Antioksidan bekerja dengan cara mendonorkan satu elektronnya kepada senyawa yang bersifat oksidan sehingga aktivitas senyawa oksidan tersebut dapat dihambat (Winarti, 2010).

Senyawa antioksidan yang bereaksi dengan radikal DPPH menyebabkan absorbsi DPPH akan berkurang yang ditandai dengan adanya perubahan warna radikal bebas DPPH yang berwarna ungu menjadi kuning pucat (Haeria dan Andi, 2016). Hal ini juga terjadi pada pengujian aktivitas antioksidan terhadap krim ekstrak etanol daun Murbei, di mana terjadinya perubahan warna larutan DPPH yang berwarna ungu pekat menjadi ungu pucat. Sedangkan, pada larutan pembanding Vitamin C terjadi perubahan warna larutan DPPH yang berwarna ungu, menjadi kuning pucat. Sehingga, dapat dikatakan bahwa larutan uji sampel krim dan larutan Vitamin C memiliki aktivitas antioksidan yang dapat mengurangi radikal bebas DPPH.

Berdasarkan hasil uji aktivitas antioksidan yang dilakukan pada sediaan krim FI, FII dan FIII diperoleh nilai $\mathrm{IC}_{50}$ beruturut-turut yaitu 1,7831 ppm, 0,8215 ppm dan 0,7668 ppm. Selain itu, larutan Vitamin $\mathrm{C}$ sebagai pembanding juga memperoleh nilai $\mathrm{IC}_{50}$ sebesar $1,1113 \mathrm{ppm}$. Semakin tinggi konsentrasi ekstrak yang terkandung dalam sediaan krim, maka semakin tinggi pula aktivitas antioksidan. Nilai yang diperoleh tersebut menunjukkan bahwa krim FI, FII, FIII dan Vitamin C, memiliki aktivitas antioksidan yang sangat kuat. Hal ini sesuai dengan kategori penentuan kekuatan aktivitas 
antioksidan menurut Molyneux (2004), yang menyatakan bahwa suatu senyawa memiliki aktivitas antioksidan sangat kuat apabila nilai IC50 < 50 ppm, kuat apabila 50-100 ppm, sedang apabila 101-150 ppm dan lemah apabila nilai IC50 $>150 \mathrm{ppm}$.

\section{KESIMPULAN}

Ekstrak etanol daun Murbei (Morus alba L.) dapat diformulasikan dalam bentuk sediaan krim, serta memenuhi syarat dalam evaluasi fisik dan uji stabilitas sediaan krim. Sediaan krim FI, FII dan FIII, diperoleh nilai $\mathrm{IC}_{50}$ beruturut-turut yaitu $1,7831 \mathrm{ppm}, 0,8215 \mathrm{ppm}$ dan $0,7668 \mathrm{ppm}$. Nilai menunjukkan bahwa krim FI, FII, FIII memiliki aktivitas antioksidan yang sangat kuat.

\section{SARAN}

Perlu dilakukan penelitian lebih lanjut untuk sediaan krim ekstrak etanol daun Murbei mengenai uji viskositas, uji iritasi dan uji antibakteri.

\section{DAFTAR PUSTAKA}

Departemen Kesehatan Republik Indonesia. 1979. Farmakope Indonesia. Edisi ke-3. Departemen Kesehatan Republik Indonesia, Jakarta.

Haeria, H., dan Andi, T., U. 2016. Penentuan Kadar Flavonoid Total dan Aktivitas Antioksidan Ekstrak Etanol Daun Bidara (Ziziphus spina- christi L.). Journal of Pharmaceutical and Medicinal Science (1): 57-61.

Hanani, E., A. Mun'im, dan R. Sekarini. 2005. Identifikasi Senyawa Antioksidan dalam Spons callyspongia sp. Dari Kepulauan Seribu. Majalah Ilmu Kefarmasian. 2(3): $127-133$.

Jurian, Y. V. 2016. Aktivitas Antioksidan dan Antibakteri Ekstrak Daun Murbei (Morus alba) Terhadap Escherichia coli [skripsi]. Universitas Jember, Jember.

Megawati, Aswad, M. Embu, dan Khadijah. 2019. Uji Aktivitas Antioksidan Ekstrak Etanol Daun Murbei (Morus Alba L.) Asal Kupang, Nusa Tenggara Timur Dengan Metode DPPH (2,2 Diphenil-1Picrylhydrazyl). Techno. 8(1): 246-252.
Molyneux, P. 2004. Use of The Stable Free Radical Diphenylpicrylhydrazil (DPPH) for Estimating Antioxidant Activity. Journal of Science and Technologi. 26(2): 211- 219.

Radhia, R., A.N. Aisyah, A. Awaluddin, dan Nurindasari. 2017. Formulasi Krim Pemutih dari Fitosom Ekstrak Daun Murbei (Morus alba L.). JF FIK UINAM. 5(4): 233-238.

Rahmawati, D., A. Sukmawati, dan P. Indrayudha. 2010. Formulasi Krim Minyak Atsiri Rimpang Temu Giring (Curcuma heyneana Val \& Zijp): Uji sifat fisik dan daya antijamur terhadap Candida albicans secara in vitro. Maj. Obat Trad. 15: 56-63.

Salem, M., H. Ali., Y. Gohar, dan A.W. El-Sayed. 2013. Biologycal Activity of Extract from Morus alba L., Albizzia Lebbeck (L.) Benth. And Casuarina Gluacca Sieber Against The Growth of some Pathogenic Bacteri. International Journal of Agricultural an Food Research. 2(1): 922.

Sharon, N., S. Anam, dan Yuliet. 2013. Formulasi Krim Ekstrak Etanol Bawang Hutan (Eleutherine palmifolia L. Merr). Online Jurnal of Natural Science. 2(3): 111-122.

Tranggono, R.I., Latifah, F. 2007. Buku Pegangan Ilmu Pengetahuan Kosmetik. Gramedia Pustaka Utama, Jakarta. Halaman 33-36.

Wasitaatmadja, S.M. 1997. Penuntun Ilmu Kosmetik Medik. Penerbit Universitas Indonesia, Jakarta. Hal. 3,58- 59.62-63. 111-112.

Widiastuti, N. 2010. Pengukuran Aktivitas Antioksidan dengan Metode CUPRAC, DPPH, \& FRAP Serta Kolerasinya dengan Fenol dan Flavonoid pada Enam Tanaman [Skripsi]. FMIPA Institut Pertanian, Bogor.

Winarti, S. 2010. Makanan Fungsional. Graha Ilmu, Yogyakarta. 